Перспективи подалыших наукових розвідок вбачаємо в здійсненні порівняльного аналізу критеріїв Нової української школи та вимог В. Сухомлинського до оформлення класної кімнати початкової школи, в аналізі стендів як складової освітнього простору закладу освіти.

\section{СПИСОК ВИКОРИСТАНОЇ ЛІТЕРАТУРИ}

1. Библюк М. Прихована програма школи Василя Сухомлинського / М. Библюк // Шлях освіти. - 2004. № 1. - C. 41-45.

2. Класна кімната [Електронний ресурс]. URL: https://uk.wikipedia.org/wiki/\%d0\%9a\%d0\%bb\%d0\% b0\%d1\%81\%d0\%bd\%d0\%b0 \%d0\%ba\%d1\%96\%d0\% $\mathrm{bc} \% \mathrm{~d} 0 \% \mathrm{bd} \% \mathrm{~d} 0 \% \mathrm{~b} 0 \% \mathrm{~d} 1 \% 82 \% \mathrm{~d} 0 \% \mathrm{~b} 0$ (дата звернення: 20.06.2019).

3. Нова українська школа: порадник для вчителя / за заг. ред. Н. М. Бібік. - К. : ТОВ «Видавничий дім «Плеяди», 2017. - 206 с.

4. Панов В. И. Психодидактика образовательных систем: теория и практика. / В. И. Панов. - СПб. : Питер, 2007. $-352 \mathrm{c}$.

5. Петренко О. Б. Роль шкільного середовища Павлиської середньої школи часів В. Сухомлинського в розвитку креативності учнів / О. Б. Петренко // Спадщина В. О. Сухомлинського - джерело сучасної педагогічної науки і практики : монографія. - Луцьк : Надстир'я, 2016. - С. 63-73.

6. Сухомлинская О. В. Идеи и свершения Василия Александровича Сухомлинского / О. В. Сухомлинская // Советская педагогика. - 1988. - № 9. C. $11-17$.

7. Сухомлинська О. В. Школа Сухомлинського у Павлиші - погляд крізь призму часу : науково-популярне видання / О. В. Сухомлинська. - К. : Педагогічна думка, 2013. - 124 с.

8. Сухомлинський В. О. Павлиська середня школа / В. О. Сухомлинський // Вибрані твори : в 5 т. - К. : Рад. школи, 1977. - Т. 4. - С. 7-390.

9. Сухомлинський В. О. Розмова з молодим директором школи / В. О. Сухомлинський // Вибрані твори : в 5 т. - К. : Рад. шк., 1977. - Т. 4. - С. 393-626.

10. Сухомлинський В. О. Серце віддаю дітям / В. О. Сухомлинський // Вибрані твори : в 5 т. - К. : Рад. шк., 1976. - Т. 3. - С. 7-282.

11. Ясвин В. А. Образовательная среда: от моделирования к проектированию / В. А. Ясвин. - М. : Смысл, 2001. - 365 с.

Дата надходження до редакиї: 06.08.2019 p.

Віктор ШВИдУН, кандидат педагогічних наук, доиент, заступник декана факультету підготовки та перепідготовки педагогічних кадрів КЗВО «Дніпровська академія неперервної освіти» Дніпропетровської обласної ради, м. Дніпро

\title{
УПРАВЛІННЯ ПІСЛЯДИПЛОМНОЮ ПЕДАГОГІЧНОЮ ОСВІТОЮ ЯК СКЛАДОВОЮ ОСВІТИ В УКРАЇНІ
}

У статті розглядаються питання модернізаиії системи післядипломної педагогічної освіти в Україні. Визначаються основні положення методологіі післядипломної педагогічної освіти та функиї̈ педагогічного прочесу в контексті необхідності продовження реформування украӥнської школи через послідовну реалізацію комплексу взаємопов'язаних заходів.

Ключові слова: компетентність, інновачї̈, післядипломна педагогічна освіта, самоосвіта, функиії післядипломної педагогічної освіти.

В статье рассматриваются вопросы модернизаици системы последипломного педагогического образования в Украине. Определяются основные положения методологии последипломного педагогического образования и функиии педагогического проиесса в контексте необходимости продолюения реформирования украинской школь через последовательную реализаиию комплекса взаимосвязанных мероприятий.
Ключевые слова: компетентность, инновачии, последипломное педагогическое образование, самообразование, функиии последипломного педагогического образования.

The article deals with the issues of modernization of the postgraduate pedagogical education system in Ukraine. The main points of the postgraduate pedagogical education methodology are determined, since it is precisely what provides human education for most of his life. In particular, the focus is on concentrating not only on supporting traditional post-graduate education mechanisms, but on developing new ones, aimed at adapting to tasks related to systemic restructuring both in education and society as a whole. Modern postgraduate education is possible only on the basis of a combination of the actual system of postgraduate pedagogical education and self-education of teachers in the process of carrying out professional duties. That is why it is about creating a continuous system 
of self-education of teachers using the organizing and coordinating potential of structures of postgraduate education.

The functions of postgraduate pedagogical education are considered by us as a function of organized systems (pedagogical, social, technical) that provide the realization of the goal of the given branch of education, support of activity, sustainability and development of certain structural elements. The content of managerial functions is the organization of effective interaction of entities in this system, taking into account changes in the environment.

On the basis of the analysis of scientific research of a number of Ukrainian scientists, their scientific achievements are systematized and the most relevant for the modern postgraduate pedagogical education are defined: development of teachers'; informational; coordinative; stimulating; research.

Key words: competence, innovations, postgraduate pedagogical education, self-education, functions of postgraduate pedagogical education.

Постановка проблеми. Як відзначається в Концептуальних засадах реформування середньої школи, «... українська школа не готує до успішної самореалізації в житті. Український школяр отримує в школі здебільшого суму знань. Потрібна докорінна реформа» $[5$, с. 4]. У зв'язку з цим, на нашу думку, одним із викликів інформаційного суспільства $є$ необхідність кардинальної трансформації освітньої галузі України в цілому та післядипломної педагогічної освіти 3окрема, підвищення вимог до професійної компетентності педагогів, оскільки вони мають бути суб'єктами позитивних змін.

Аналіз наукових досліджень і публікацій. Наявна джерельна база $з$ проблем розвитку управління післядипломною педагогічною освітою в Україні представлена значною кількістю досліджень, серед яких варто виокремити праці В. Бондар, I. Жерносєка, Л. Даниленко, С. Крисюка, А. Кузьмінського, В. Лугового, В. Маслова, В. Олійника, Н. Протасової, В. Пуцова, В. Швидуна та ін.

Відзначаючи значний доробок учених у розкриття особливостей управління післядипломною педагогічною освітою в Україні, вважаємо за доцільне продовжити поліаспектний аналіз даного процесу.

Мета статті полягає в обгрунтуванні необхідності подальшого розвитку системи управління післядипломною педагогічною освітою через модернізацію положень методології означеної галузі освіти та оновлення функцій у контексті подолання недоліків, притаманних професійній діяльності вчителів.

Виклад основного матеріалу. У Законі України «Про вищу освіту» післядипломна освіта визначається як «... спеціалізоване вдосконалення освіти та професійної підготовки особи шляхом поглиблення, розширення та оновлення іiі професійних знань, умінь та навичок або отримання іншої професії, спеціальності на основі здобутого раніше освітнього рівня та практичного досвіду» [1].

Стосовно післядипломної педагогічної освіти, то погоджуємося $з$ визначенням В. Олійника, який трактує іiі як «... галузь освіти дорослих, що забезпечує неперервне вдосконалення професійних знань, умінь і навичок педагогічних, науково-педагогічних та керівних кадрів освіти шляхом підвищення кваліфікації, перепідготовки, спеціалізації та стажування на основі новітніх технологій, досягнень науки і виробництва» [6, с. 682].
Основні положення методології післядипломної педагогічної освіти визначимо на основі таких положень:

1. Післядипломній освіті варто відвести пріоритетне місце в сучасних освітніх системах, оскільки саме вона забезпечує освіту людини впродовж значної частини її життя.

2. Система післядипломної педагогічної освіти у найближчому майбутньому має стати не просто системою підвищення кваліфікації, а єдиним механізмом переорієнтації педагогів стосовно змісту, форм навчання, системи ціннісних орієнтирів, засобів комунікації тощо. Основну увагу при цьому слід звертати не так на підтримку традиційних механізмів післядипломної освіти, як на розбудову нових, спрямованих на адаптацію до завдань, пов'язаних із системною перебудовою і в освіті, і в суспільстві в цілому.

3. Післядипломна педагогічна освіта має стати основою формування неперервної системи освіти впродовж життя для всіх педагогів регіону. Така система не може будуватися на основі принципів дискретної освіти, які застосовувалися у післядипломній освіті до останнього часу. Вона вимагає виходу післядипломної освіти за межі інституційної обмеженості та інтеграції в освітній процес, який здійснюється у навчальних закладах. Сучасна післядипломна освіта можлива лише на основі поєднання власне системи післядипломної педагогічної освіти та самоосвіти педагогів у процесі здійснення професійних обов'язків, тобто йдеться про створення неперервної системи самоосвіти педагогів 3 використанням організуючо-координуючого потенціалу структур післядипломної освіти.

4. Механізми формування такої системи самоосвіти на основі реалізації післядипломною педагогічною освітою своїх координуючо-організаційних функцій підказує сама освітня практика.

По-перше, це - поступовий перехід до тематичних курсів, які мають зрештою стати основою роботи закладів післядипломної педагогічної освіти. Саме це завдання є сьогодні ключовим, адже йдеться про наближення освіти до споживача освітніх послуг, індивідуалізацію та диференціацію освітніх послуг, урахування побажань педагогів при складанні програм післядипломної освіти.

По-друге, це - інтеграція в систему післядипломної освіти мережі експериментальної та науково-дослідної роботи освітніх закладів. Практика показує, що інноваційна діяльність на робочому місці є найкращою формою підвищення кваліфікації будь-якого педагога. Вона стимулює до самостійної роботи й оволодіння сучасними педагогічними технологіями, формує нові ціннісні орієнтири освітньої діяльності, та, крім того, є фактично єдиним засобом реалізації стратегічних цілей модернізації освіти на операційно-практичному рівні. Отже, інноваційна діяльність педагогів є не лише формою післядипломної освіти, а й ресурсом навчання та самонавчання інших педагогів та педагогічних колективів. При цьому завдання закладів післядипломної педагогічної освіти - розвивати та повноцінно використовувати означений ресурс.

Таким чином, уважаємо за доцільне детальніше окреслити функції педагогічного процесу в системі післядипломної педагогічної освіти. Проаналізувавши дослідження А. Кузьмінського [3], В. Лугового [4] та Н. Протасової [7], виділимо такі функції:

- адаптивну - спрямована на адаптацію педагога до своєї професії, швидкозмінних умов педагогічної праці, трансформації моральних, духовних, ціннісних орієнтацій сучасного суспільства; 
- компенсаторну - має на меті відтворення частково втрачених або раніше неодержаних знань, а також розширення та оновлення педагогічної підготовки;

- аналітичну - передбачає критичне осмислення наявної педагогічної реальності, забезпечує аналіз та оцінку власної професійної діяльності;

- рефлексивну - $є$ важливою умовою конструктивного вдосконалення особистості педагога;

- перетворювальну - спрямована на подолання сформованих і застарілих стереотипів діяльності, негативних налаштувань;

- розвивальну - забезпечує розвиток педагога як особистості й професіонала;

- прогностичну - спрямована на передбачення результатів педагогічної діяльності, іiї проектування;

- стимулювальну - покликана підтримувати й заохочувати педагога до вдосконалення, самоосвіти та саморозвитку [3, с. 220-223; 4, с. 174-175; 7, с. 120-122].

Поділяючи погляди означених вище науковців, відзначимо, що функції післядипломної педагогічної освіти розглядаються нами як функції організованих систем (педагогічних, соціальних, технічних), що забезпечують реалізацію мети даної галузі освіти, підтримку діяльності, сталість та розвиток певних структурних елементів. Змістом управлінських функцій є організація ефективної взаємодії суб'єктів у даній системі з урахуванням змін зовнішнього середовища. Це дає підстави систематизувати наукові здобутки і вважати найбільш актуальними для сучасної післядипломної педагогічної освіти такі функції:

- розвитку професіоналізму педагогів - створення умов для оновлення, поглиблення професійних знань, умінь і навичок; здобуття нової спеціальності, кваліфікації; індивідуалізація професійного розвитку педагога;

- інформаційну - створення, розповсюдження, накопичення інформації загальноосвітнього, загальнокультурного та власне педагогічного характеру; створення регіональної системи інформаційного забезпечення післядипломної педагогічної освіти;

- координаиійну - адаптація педагога до своєї професії, швидкозмінних умов педагогічної праці, розширення та оновлення педагогічної підготовки, аналіз та оцінка власної професійної діяльності, подолання сформованих і застарілих стереотипів діяльності;

- стимулюючу - мотивація та підтримка до освіти і самоосвіти, кар'єрного зростання, здобуття нової спеціальності, кваліфікації;

- науково-дослідну - проектування педагогічної діяльності, розробка нових педагогічних методик технік, апробація інноваційних освітніх технологій.

Саме тому актуальним $є$ питання внесення змін у методологію управління післядипломною педагогічною освітою, оскільки забезпечити якість швидких, всеохоплюючих змін, характерних для сучасного етапу розвитку цивілізації, повинна система освіти. Необхідно розвинути природні здібності кожної людини, навчити самостійно здобувати знання, креативно мислити, швидко опрацьовувати значний об'єм інформації, сприймати та впроваджувати інновації. Ключова роль у вирішенні визначених завдань, без сумніву, має належати вчителеві, викладачу. Однак для цього, на нашу думку, функції управління післядипломною педагогічною освітою насамперед мають бути спрямовані на підвищення професійної компетентності педагогів як ключового фактора оновлення змісту освіти та технологій навчання, узгодження їх iз сучасними потребами, тобто на оновлення змісту навчання, створення нових програм, трансформацію навчально-методичної бази в контексті реалізації компетентнісного підходу як у післядипломній педагогічній освіті зокрема, так і в системі освіти в цілому.

Аналізуючи сучасний стан педагогічної практики в Україні, неможливо не звернути уваги на суттєві недоліки, характерні для професійної діяльності вчителів, серед яких варто виокремити такі:

- значна частина педагогів продовжує працювати так, як працювали десять, і двадцять, і тридцять років тому, незважаючи на нові вимоги сьогодення;

- рівень інформації з кожним роком стає все вищим, а отже, необхідно усвідомити, що навчити учня в школі всього і на все життя неможливо, необхідно акцентувати увагу на передачі лише базових знань, зацікавлюючи учня в необхідності додаткового отримання інформації самостійно, тобто навчити здобувати знання, а не отримувати їх у готовому, «опрацьованому» вигляді, як це традиційно практикується в школі;

- масова підготовка педагогів (зокрема й у класичних університетах) за відсутності належної педагогічної практики не забезпечує їх належну підготовку до індивідуально-творчого характеру педагогічної діяльності, тобто рівень базової підготовки вчителів не узгоджується з новими, постійно зростаючими вимогами до представників педагогічної професії.

У даному контексті, на нашу думку, доцільним для української системи післядипломної педагогічної освіти є орієнтація на так звані Лісабонські стратегії, ухвалені ще в березні 2000 р. Вони визначають шість найважливіших принципів неперервного навчання:

- нові базові навички для всіх (забезпечення широкого і постійного доступу до освіти для одержання і поновлення навичок, необхідних в інформаційному суспільстві);

- збільшення інвестицій у сферу персоналу (істотне збільшення інвестицій у людські ресурси з метою встановлення пріоритету найважливішого надбання Свропи - людей);

- нові тенденції у викладанні та вивченні (розробка ефективних методів викладання і навчання в контексті реалізації положення про навчання впродовж життя у всіх його проявах);

- нова система оцінювання отриманої освіти (вдосконалення способів моніторингу якості освіти, особливо у сфері неофіційної та неформальної освіти);

- перегляд практики управління та консультацій (забезпечення всім бажаючим доступу до високоякісної освіти та інформації про вільний вибір місця навчання на всій території Свропи впродовж життя);

- перенесення процесів навчання ближче до людини (надання можливості безперервного навчання індивіду за місцем проживання чи роботи за підтримки інформаційних технологій) [2, с. 238-239].

Розвиток системи післядипломної педагогічної освіти передбачає продовження реформування управління даною галуззю, оскільки саме вона покликана сприяти забезпеченню потреб держави у кваліфікованих кадрах високого рівня професіоналізму та культури, які здатні компетентно та відповідально виконувати посадові обов'язки, впроваджувати новітні технології, сприяти подальшому соціальноекономічному розвитку суспільства. Стратегія роботи закладів системи післядипломної педагогічної освіти має бути трансформована. Вважаємо, що пріоритетним напрямом при цьому має бути не забезпечення функціонування системи освіти, а іi інноваційний розвиток, що передусім передбачає перехід від ретрансляційних завдань до дослідницьких, 
виявлення та задоволення освітніх потреб педагогів, вивчення специфіки освітніх процесів, їх модернізацію.

Висновки. Таким чином, розглянувши управління післядипломною педагогічною освітою як складовою освіти в Україні, ми дійшли певних висновків. Глобалізаційні процеси суттєво впливають на регулювання системи освіти усіх без винятку держав, оскільки саме освіта формує та конституює культурні потреби, смисложиттєві орієнтири, базові цінності всіх членів суспільства. Післядипломна педагогічна освіта у даному контексті розглядається нами як один із найважливіших напрямів діяльності будь-якої держави, адже забезпечує розширення й оновлення професійних знань, розвиток компетенцій та набуття практичного досвіду дорослими людьми упродовж значного періоду свого життя.

Функції післядипломної педагогічної освіти як складової освіти в Україні багатоаспектні та поліфункціональні й розглядаються нами як функції організованих систем (педагогічних, соціальних, технічних), що забезпечують реалізацію мети даної галузі освіти, підтримку діяльності, сталість та розвиток певних структурних елементів.

Модернізація механізмів управління післядипломною педагогічною освітою має передбачати послідовну реалізацію комплексу взаємопов'язаних заходів, зокрема компетентнісного підходу та різних форм навчання, наприклад, формального, неформального, спонтанного (позаформального), безперервного, дистанційного.

Подальші наші дослідження плануємо спрямувати на аналіз досвіду системи післядипломної педагогічної освіти зарубіжних країн із метою виокремлення позитивних напрацювань та розробки конкретних механізмів їх реалізації в системі післядипломної педагогічної освіти України.

\section{СПИСОК ВИКОРИСТАНОЇ ЛІТЕРАТУРИ}

1. Закон України «Про вищу освіту» від 01.07.2014 №1556-VII [Електронний ресурс]. URL: http://zakon5.rada.gov.ua/laws/show/1556-18 (дата звернення: 20.05.2019).

2. Колесник В.Ю. Становлення та розвиток політики Свропейського Союзу у сфері освіти / В.Ю. Колесник // Вісник Чернівецького факультету національного університету «Одеська юридична академія». - 2014. № 1. - С. 232-250.

3. Кузьмінський А. I. Теоретико-методологічні засади післядипломної педагогічної освіти в Україні : дис. ... доктора пед. наук : 13.00.04 / Кузьмінський Анатолій Іванович. - К., 2003. - 443 с.

4. Луговий В. І. Педагогічна освіта в Україні: структура, функціонування, тенденції розвитку : [монографія] / В. І. Луговий ; [за заг. ред. акад. О. Г. Мороза]. - К. : МАУП, 1994. - 196 с.

5. Нова українська школа. Концептуальні засади реформування середньої школи [Електронний pecypc]. URL: https://www.kmu.gov.ua/storage/app/ media/reforms/ukrainska-shkola-compressed.pdf__дата звернення: 21.05.2019).

6. Олійник В. В. Післядипломна педагогічна освіта / В. В. Олійник // Енциклопедія освіти / Акад. пед. наук України ; гол. ред. В.Г. Кремень. - Київ : Юрінклм Інтер, 2008. - С. 682-683.

7. Протасова Н.Г. Післядипломна освіта педагогів: зміст, структура, тенденції розвитку / Н. Г. Протасова. - К. : Шкільний світ, 1998. - 176 с.

Дата надходження до редакиії: 23.05.2019 p.

\section{ОСОБЛИВОСТІ ФАХОВОЇ ДІЯЛЬНОСТІ ТА ПРОФЕСІЙНОЇ ПІДГОТОВКИ ВЧИТЕЛЯ ПРЕДМЕТА «ЗАХИСТ ВІТЧИЗНИ»}

У статті охарактеризовано зміст і иілі предмета «Захист Вітчизни», а також розглянуто вимоги до його викладання. Висвітлено особливості фаховоі діяльності та можливості вдосконалення професійної підготовки вчителя, який викладає дану дисичипліну.

Ключові слова: навчальний предмет, учитель предмета «Захист Вітчизни», підготовка вчителя, фахова діяльність, професійна підготовка.
В статье охарактеризованы содержание и иели предмета «Зашита Отечества», а также рассмотрены требования к его преподаванию. Освещуены особенности профессиональной деятельности и возможности совершенствования профессиональной подготовки учителя, который преподает данную дисициплину.

Ключевые слова: учебный предмет, учитель предмета «Защита Отечества», подготовка учителя, профессиональная деятельность, профессиональная подготовка. 